Pobrane z czasopisma Annales H - Oeconomia http://oeconomia.annales.umcs.pl Data: 26/04/2023 14:36:00

DOI:10.17951/h.2015.59.3.81

\begin{tabular}{lc}
\hline & A N N A L E S \\
UNIVERSITATIS & MARIAE CURIE-SKŁODOWSKA \\
LUBLIN - POLONIA & SECTIOH H \\
VOL. XLIX, 3 & 2015 \\
\hline
\end{tabular}

Maria Curie Skłodowska University, Marketing Department

YEVHEN KRYKAVSKYY

ROKSOLANA WORONINA

ywkryk@polynet.lviv.ua, voroninaroksolana@gmail.com

\title{
The Impact of Globalization on the Development of City Logistics
}

Wpływ globalizacji na rozwój logistyki miasta

Keywords: city logistics, urban mobility, globalization, urbanization, global city.

Słowa kluczowe: logistyka miejska, miejska mobilność, globalizacja, urbanizacja, globalne miasto.

JEL Code: F63, R41

\section{Introduction}

Globalization leads to urbanization, but uncontrolled urbanization can lead to aggravation of social and environmental issues, as well as city's economy.

It is estimated that by 2050 , approximately $70 \%$ of world population will live in urban areas. Moreover, considering current trends, more people are willing to use private motorized transport. Approximately 6.2 billion private motorized trips are made every day in cities. By 2050, an urban dweller will spend around 106 hours per year in traffic jams that is three times more than today. And what is worse, around 0.5 million people will be killed in road traffic accidents every year (Arthur, 2014, p. 4).

Nevertheless, this could be changed if innovations are implemented in urban development and infrastructure in the meantime. This would create significant challenges for city management and especially city logistics, which should provide both for the needs of residents and businesses operating in it. 


\section{The impact of globalization on urban development}

Since recently, urban development in the world is closely examined in the area of logistics - both theory and practice. Each city is subject to constant changes, which may be a phase of development, crises, setbacks, and even extinction.

Organizational and economic structure of the city is a consequence of the era in which the city developed. Often, this development is anarchic and fragmented according to the facilities available.

According to the Athenian map (1933), city functions include: accommodation + work + vacation + utilities + communication. Thus, communication infrastructure and logistics are treated as a means of implementing all functions of the city, which means special composition of relations "city - transport."

World population is increasingly city-based. Cities occupy $2 \%$ of the Earth and concentrate more than half of people in the world. In 1950, approximately $30 \%$ of world population lived in urban areas, in 2003 - urban population was $48 \%$ and in 2050 it is expected to be $66.5 \%$, and in developed countries even more $-85.4 \%$, or almost 6.4 billion people.

Figure 1. Percentage of population residing in urban areas in the world in years 2000-2050

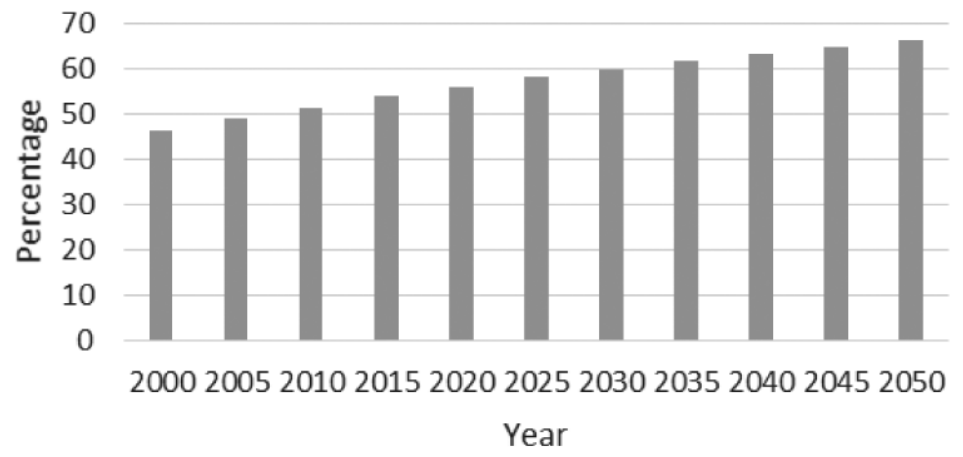

Source: author's own study on the basis of UN, 2014, p. 20

Due to continuing population growth and urbanization of Asia and Africa, nearly $90 \%$ of the increase is concentrated in these countries.

Just three countries - India, China, and Nigeria are expected to account for $37 \%$ of the projected growth of the world's urban population between 2014 and 2050 (UN, 2014, p.1). Several decades ago, most of the world's largest urban agglomerations were in the more developed regions, but today's large cities are concentrated in the Asia and Africa.

By 2030, 30 largest urban agglomerations will include only 2 cities in United States of America - New York and Los Angeles, and none European city. 
Pobrane z czasopisma Annales H - Oeconomia http://oeconomia.annales.umcs.pl

Data: 26/04/2023 14:36:00

THE IMPACT OF GLOBALIZATION ON THE DEVELOPMENT OF CITY LOGISTICS

Table 1. 10 Largest Urban Agglomerations Ranked by Population Size in years 1950-2030

\begin{tabular}{|c|c|c|c|c|c|c|c|c|c|}
\hline \multirow[b]{2}{*}{ 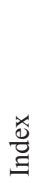 } & \multicolumn{3}{|c|}{1950} & \multicolumn{3}{|c|}{2000} & \multicolumn{3}{|c|}{2030} \\
\hline & $\begin{array}{l}\text { Urban } \\
\text { Agglom- } \\
\text { eration }\end{array}$ & $\begin{array}{c}\text { Country } \\
\text { or area }\end{array}$ & $\begin{array}{l}\text { Popula- } \\
\text { tion }(\mathrm{mln})\end{array}$ & $\begin{array}{l}\text { Urban } \\
\text { Agglom- } \\
\text { eration }\end{array}$ & $\begin{array}{c}\text { Country } \\
\text { or area }\end{array}$ & $\begin{array}{l}\text { Popula- } \\
\text { tion }(\mathrm{mln})\end{array}$ & $\begin{array}{l}\text { Urban } \\
\text { Agglom- } \\
\text { eration }\end{array}$ & $\begin{array}{c}\text { Country or } \\
\text { area }\end{array}$ & $\begin{array}{c}\text { Popula- } \\
\text { tion } \\
(\mathrm{mln})\end{array}$ \\
\hline 1 & New York & USA & 12.34 & Tokyo & Japan & 34.45 & Tokyo & Japan & 37.19 \\
\hline 2 & Tokyo & Japan & 11.27 & Osaka & Japan & 18.66 & Delhi & India & 36.06 \\
\hline 3 & London & $\begin{array}{l}\text { United } \\
\text { Kingdom }\end{array}$ & 8.36 & $\begin{array}{c}\text { Mexico } \\
\text { City }\end{array}$ & Mexico & 18.46 & Shanghai & China & 30.75 \\
\hline 4 & Osaka & Japan & 7.01 & New York & USA & 17.81 & Bombay & India & 27.80 \\
\hline 5 & Paris & France & 6.28 & São Paulo & Brazil & 17.01 & Beijing & China & 27.71 \\
\hline 6 & Moscow & Russia & 5.36 & Bombay & India & 16.37 & Dhaka & Bangladesh & 27.37 \\
\hline 7 & $\begin{array}{c}\text { Buenos } \\
\text { Aires }\end{array}$ & Argentina & 5.10 & Delhi & India & 15.73 & Karachi & Pakistan & 24.84 \\
\hline 8 & Chicago & USA & 5.00 & Shanghai & China & 13.96 & Cairo & Egypt & 24.50 \\
\hline 9 & Calcutta & India & 4.51 & Cairo & Egypt & 13.63 & Lagos & Nigeria & 24.24 \\
\hline 10 & Shanghai & China & 4.30 & Calcutta & India & 13.06 & $\begin{array}{c}\text { Mexico } \\
\text { City }\end{array}$ & Mexico & 23.86 \\
\hline
\end{tabular}

Source: author's own study on the basis of Institute for Urban Strategies, 2014, p. 26

Globalization has become associated with multi-nodal, policy/planning responses and has brought in new concept of "world city" or "global city" that means a city generally considered to be an important node in the global economic system. These cities have a direct and tangible effect on global affairs through socio-economic means.

The Global Power City Index (GPCI) is an important index in assessing global cities. It evaluates and ranks the major cities of the world according to their comprehensive power which allows them to attract creative individuals and business enterprises from every continent and to mobilize their assets in securing economic, social and environmental development.

According to the 2014 GPCI, the cities with the highest rating are: London, New York, Paris, Tokyo, Singapore, Seoul, Amsterdam, Berlin, Hong Kong, and Vienna (Institute for Urban Strategies, 2014, p. 3). We can see that, although European and American cities lose their position as the largest urban agglomerations, they remain the most influential cities in the world. However, there is no forecast of this index for the future, therefore, it is possible that Asian cities such as Hong Kong will gain more global power.

Challenges of sustainable development in cities continue to increase, especially in developing countries, where the urbanization is growing faster. Governments must implement policies to ensure that the benefits of urban growth are shared equitably and sustainably. Such benefits are better health care and education, public transpor- 
tation, as well as housing, electricity, water, and sanitation that is cheaper and less harmful for the environment than in rural households. Also, people in urban areas have access to better labour markets.

The relevant trend towards urban development increases traffic intensity. Research shows that this increase is uneven. On the other hand, traffic growth is perceived by the population as one of the most significant factors affecting the quality of life in cities, causing air pollution and noise. The intensity of vehicles provoke speed decrease and congestions. In the economic sense, this negative effect of delays results in additional cost of transport processes (operational costs, infrastructure costs etc.).

Due to such situation, new challenges emerge for people and the planet, such as:

- air and noise pollution;

- $\mathrm{CO}_{2}$ emission;

- increasing ecological footprint;

- traffic chaos and traffic jams;

- decreasing quality of people`s life;

- overloaded infrastructures;

- insufficient public transport capacities;

- limited parking places.

The above economic and environmental aspects of a single component of city logistics system - transport - require, firstly, an integrated approach to research and optimization, and, secondly, the introduction of innovative solutions, as well as technological and organizational management.

\section{The development of city logistics}

The problem of city management transformed into the formation of city logistics concept. The growing importance of city logistics in the modern economy came from the new paradigm of city internationalization.

The term "city logistics" professed systematic approach principles, logistics coordination and movement orientation. The subject of city logistics research is much more difficult. It covers the issues of supply of water, gas, electricity, and heat, issues of passenger and freight transportation, considering warehousing, waste utilization and communication issues.

Developed understanding of city logistics actualizes strategic decisions, first, for creating the optimal configuration of city logistics network. Based on the general concept of logistics, the concept of decisions on a city should be based on cost and benefit analysis, however, customer care (resident, passenger, etc.) is at the forefront. In other words, high-quality communications and transport services are stipulated. Secondly, strategic decisions of city logistics include effective tools for overcoming the consequences of "time compression" in the implementation of urban logistics 
flows. International experience representing such instruments is based on telematics. The problem of urban logistics is also associated with the development of SMEs in these cities, especially its needs in transport and logistics services.

Important goals in urban logistics relate to the notions of competitiveness and attractiveness of the territories, which suggests the possibility of their development and improvement. The competitiveness of a region indicates the effectiveness of activities carried out there, which in itself may depend on the efficiency of local conditions. Establishing logistic objects creates competitive conditions in different areas and logistics affects the attractiveness of these areas in return.

Provided logistics services in corresponding economic zone is another factor affecting the spatial organization of city logistics. This service must be easily accessible. Logistics service providers are generally concentrated in the metropolitan area. Indeed, establishing enterprises in a large metropolitan area is associated with lower risk, because there are major customers, clients ' customers, transport infrastructure hubs, necessary workforce and a dynamic real estate market. Thus, logistics must be important for public authorities in their spatial organization.

Summarizing, successful city and urban logistics decisions in developed countries enables us to distinguish three groups of decisions. The first one concerns the economic aspects of distribution logistics, trade, and business services. The second group of decisions concerns innovative logistics technology for flows of goods, people and information that will help implement the concept of sustainable development. The third group includes administrative decisions on the implementation of logistics flows in the city. It primarily has an administrative impact on productivity and efficiency of logistics flows.

The implementation of investment projects in major cities should be in full accordance with the selected concept of city logistics, subordinate to objectives of sustainable development. Every year most developed countries increase environmental requirements to existing logistics systems. Heavy vehicles movement is the source of a number of adverse effects (air pollution, noise, road safety reduction) and people tolerate it less and less.

Construction of large logistics area or large logistics complex, occupying an area of about a hundred acres, creates coherent structures. In this case, equipment and services are easier to organize and finance. It gives us an opportunity to organize transport operations through the use of traditional solutions such as public transport or innovative solutions, like car sharing. Car sharing became very popular in European countries and in North America and some Asian Pacific countries. It includes already popular solutions of Greenwheels / StattAuto, Stadtmobil, Communauto. It also includes innovative solutions of original equipment manufacturers such as BMW DriveNow, Daimler car2go, Volkswagen Quicar, and Citroen Multicity. In the future, operators are looking forward to turn car sharing into mass market.

In the spatial distribution of freight flows, intermediate storage plays a significant role. Specificity of logistics facilities in the spatial arrangement of the territory prima- 
rily focused on the place foreseen for them in urban planning and, as a consequence, in the relevant regulation. In this regard, optimal territorial solutions are important to create logistics infrastructure, combining acceptable distribution zones, efficient traffic flows, favoring sustainable urban mobility.

Location of logistics facilities has a serious impact on the city dwellers. At the same time, these objects should be designed to meet their needs and requirements.

It may generally be stated that local authority policy for the allocation of construction zones for storage objects had an impact on the company`s distribution strategy, with a focus on flow centralization. On the other hand, urban traffic management and rules of freight service in the city center affect logistics of companies operating in the city center.

Considering that logistics has spatial parameters and private decisions in this field have a strong impact on city development and logistics while objectives go beyond merely private interests, therefore, public authorities should take appropriate measures, in particular in determining the location of various objects. Closer interaction between the public and private sector and a holistic approach is important to ensure optimum use of territory and sustainable urban mobility.

Successful urban logistics is possible only with the use of innovative logistics technology based on supply chain concepts, efficient customer service, cross-docking, multimodal mobility, and other effective solutions, however, active administrative steps on the implementation of city logistics strategy is needed.

Public authorities have lately begun to develop some ideas to manage and contain the levels of congestion, air pollution and noise, but most of them are political or normative decisions only made to solve emergency situations.

Restrictive policies are some of the most common measures taken by the authorities. They include regulation on parking, street access, hours of operations, etc.

Following are the main objectives of city logistics research:

- reduce congestion and increase mobility of freight transportation services in urban areas;

- reduce pollution and noise contributing to reach the Kyoto targets;

- improve living conditions of city inhabitants.

One of the toughest challenges that cities face today is urban mobility as existing mobility systems are close to breakdown. This will require thorough research, analysis, and massive investment.

Sustainable urban mobility involves planning and implementing transportation needs, which, on one hand, improve access to transport infrastructure and vehicles, providing a better quality of urban life, and on the other - is achieving the objectives in view of environmental protection and improvement of environment and city development.

This can be achieved by properly chosen strategy, which helps to establish sustainable core for the system of city logistics, network the system and maintain its efficiency. 
To improve sustainable urban mobility, a thorough analysis concerning different aspects of city mobility system is essential. Urban Mobility Index introduced by the Global Management Consultancy Arthur D. Little, which assessed the mobility maturity and performance of cities worldwide, promotes a deeper analysis of urban mobility.

Table 2 presents some key criteria of Urban Mobility Index for 10 cities with top ranking.

Table 2. Top 10 cities of Urban Mobility Index, 2014

\begin{tabular}{|c|c|c|c|c|c|c|c|c|c|c|}
\hline 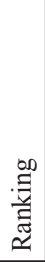 & 总莺 & 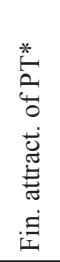 & 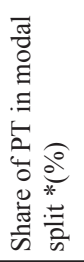 & 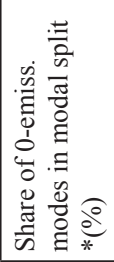 & 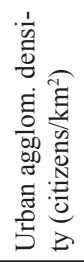 & 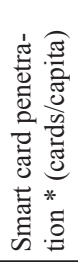 & 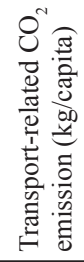 & 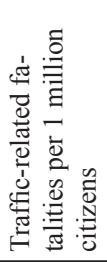 & 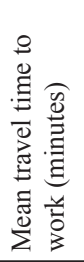 & 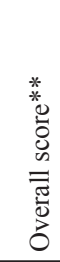 \\
\hline 1 & Hong Kong & 1.7 & 55 & 38 & 6.5 & 3.1 & 776 & 16.2 & 36.6 & 58.2 \\
\hline 2 & Stockholm & 6.7 & 33 & 34 & 3.7 & 0.6 & 1348 & 9.4 & 33.7 & 57.4 \\
\hline 3 & Amsterdam & 3.0 & 8 & 50 & 3.2 & 0.7 & 844 & 19.5 & 35.5 & 57.2 \\
\hline 4 & Copenhagen & 4.8 & 27 & 33 & 2.7 & 0.1 & 812 & 4.1 & 29.7 & 56.4 \\
\hline 5 & Vienna & 3.9 & 39 & 34 & 3.8 & 0.0 & 1111 & 16.1 & 29.3 & 56.0 \\
\hline 6 & Singapore & 2.6 & 48 & 23 & 7.3 & 2.9 & 1381 & 32.5 & 36.8 & 55.6 \\
\hline 7 & Paris & 2.9 & 34 & 50 & 3.8 & 0.6 & 1163 & 23.9 & 38.6 & 55.4 \\
\hline 8 & Zurich & 3.8 & 39 & 31 & 4.2 & 0.0 & 1200 & 15.4 & 30.4 & 54.7 \\
\hline 9 & London & 3.9 & 34 & 26 & 5.6 & 3.1 & 1050 & 26.6 & 44.1 & 53.2 \\
\hline 10 & Helsinki & 3.6 & 27 & 40 & 2.3 & 0.9 & 1228 & 13.9 & 28.5 & 53.2 \\
\hline
\end{tabular}

*Note: Criterion "Financial attractiveness of public transport" is the ratio between the price of $5 \mathrm{~km}$ journey with private means of transport and the price of $5 \mathrm{~km}$ journey with public transport within the agglomeration area.

Criterion "Share of public transport in modal split" is the percentage of total number of a person's trips, which are made with public transport in the last available measurements.

Criterion "Share of 0-emission in modal split" is the percentage of the total number of a person's trips by bicycle and walking in the last available measurements.

Criterion "Smart card penetration" is the ratio between the total number of transit smart cards in circulation in an urban agglomeration area and the population of this area.

**Overall score ranges from 0 to 100 index points and is assessed on the basis of 19 criteria.

Source: author's own study on the basis of Arthur D. Little Urban Mobility Index 2.0

As shown in Table 2, even successful cities only use half of their facilities for the development of mobility. Hong Kong is in the best position, regardless of being one of the most densely populated cities in the world. Public transport is highly used in Hong Kong, with smart card penetration of 3.1 per person. Transport-related emissions per capita is low and rate of traffic-related deaths are low as well.

Urban mobility index for Warsaw is 47.8 and is average among the assessed cities.

The need for innovation is common for all cities to improve their performance. There are many technologies and innovative solutions that can develop mobility, but the problem is in overregulated urban management systems that do not allow market players to compete and establish competent businesses. 
Study of successful urban logistics development and urban mobility improvement allow us to extinguish such innovations as Octopuscard (Hong Kong), Smart Mobility Information and ticketing system Leading the way for Effective e-mobility services (SMILE) (Vienna), Trafiken.nu (Stockholm), Path2Go (San Francisco), Stuttgart Services mobility platform.

Nowadays, information technology is developing rapidly. The evolution of logistics is closely connected with the introduction of information technologies. Internationally known companies such as Nokia, Google, Daimler, Citroen, Visa, and Mastercard offer the decision on integrated mobility platforms.

Considering the sharp increase in mobile technology innovation, transport smart cards will continue to be integrated in smartphones and other mobile devices that will be an important niche in the company`s profits and improve the quality of citizen`s life.

Greater importance should be attached to the development of appropriate training system adapted to the needs of logistics and city logistics, precisely. Research promotion is another measure that can be proposed for developing city logistics. It is also necessary to make sure that this training constantly adapts to the changing practice in order to reflect it in the research and training.

Analysts and scientists expect that cities will grow into megacities, which will be highly vascularized by eco-friendly and energy-sustainable transportation means, and filled with new dwellings and buildings made from innovative construction materials, which will be resistant, sustainable, and affordable. In addition, thanks to the interconnectivity and performance of future devices, all elements of the city will be connected to a higher supra-network, the future Internet, which will receive and transmit data (European Commision. Futurium.). But these prognoses are very optimistic and need a lot of research, innovation and investments.

\section{Conclusions}

Current and future need for inclusive and equitable urban and rural development must be thoroughly assessed with respect to urban growth using accurate, consistent and timely data. Public authorities with the help of private entities must systematically track levels and trends in urbanization and monitor progress of sustainable development goals in urban and rural areas. Successful sustainable urbanization requires competent, responsive, and accountable authorities with a clear and effective strategy, appropriate use of information and communication technologies for more efficient service delivery. Building institutional capacities and applying integrated approaches for attaining urban sustainability are needed.

Innovating in urban and city logistics will help to solve the problems stated above. Such innovation and development require significant investment, but they ensure city development, help to fight climate change, reduce greenhouse gas emissions 
and energy consumption, reduce congestion and death in a car accident, and allow residents of cities to live better.

\section{References}

1. Arthur D. Little future lab, UITP,. The Future of Urban Mobility 2.0., Arthur D. Little and UITP 2014.

2. European Commision. Futurium. At http://ec.europa.eu/digital-agenda/futurium/en/content/futurecities-villages-and-communities

3. GaWC, The World According to GAWC 2012, GAWC 2012.

4. Institute for Urban Strategies, The Miori Memorial Foundation, Global Power city Index 2014, Tokyo, 2014.

5. Tundys B. Wpływ rozwiazań z zakresu logistyki miejskiej na rozwój regionów. Zeszyty naukowe Politechniki Śląskiej, Seria: Transport, 2012, No.75.

6. United Nations, Department of Economic and Social Affairs, Population Division (2014), World Urbanization Prospects: The 2014 Revision, Highlights (ST/ESA/SER.A/352), UN, 2014.

\section{The Impact of Globalization on the Development of City Logistics}

Abstract. Globalization and urbanization can lead to aggravation of economic, social, and environmental issues, which creates significant challenges for city management and especially city logistics. These challenges require an integrated approach to research and optimization and the introduction of innovative solutions, technological and organizational direction. The implementation of investment projects in cities should be in full accordance with the selected concept of city logistics, subordinate to objectives of sustainable development. Successful urban logistics is possible only with the use of innovative logistics technology based on supply chain concepts, efficient customer service, multimodal mobility and other effective solutions, however, active administrative steps on the implementation of city logistics strategy is needed. Main objectives of city logistics research are following: reduce congestion, increase urban mobility; reduce air pollution and noise; improve living conditions of city inhabitants.

\section{Wpływ globalizacji na rozwój logistyki miasta}

Abstrakt. Globalizacja i urbanizacji może prowadzić do pogłębienia się problemów gospodarczych, społecznych i środowiskowych, co stwarza poważne wyzwania dla zarządzania miastem, a zwłaszcza logistyki miejskiej. Wyzwania te wymagają zintegrowanego podejścia do badań i optymalizacji oraz wprowadzenie innowacyjnych rozwiązań technologicznych i organizacyjnych. Realizacja projektów inwestycyjnych w miastach powinna być w pełni zgodna z wybraną koncepcją logistyki miejskiej, podporządkowanej celom zrównoważonego rozwoju. Udana logistyka miejska jest możliwa tylko przy zastosowaniu innowacyjnej technologii opartej na koncepcji logistyki w łańcuchu dostaw, sprawnej obsługi klientów, mobilności multimedialnej i innych skutecznych rozwiązań, jednak potrzebne jest aktywne działania administracyjne dotyczące realizacji strategii logistyki miejskiej. Główne cele badań logistyki miejskiej są następujące: zmniejszenie zatłoczenia, zwiększenie mobilności miejskiej; zmniejszenie zanieczyszczenia powietrza i hałasu; poprawa warunków życia mieszkańców miasta. 